\title{
PEMBERLAKUAN PERJANJIAN BAKU \\ DAN PERLINDUNGAN TERHADAP KONSUMEN
}

\author{
Hulman Panjaitan ${ }^{1}$
}

\begin{abstract}
Enforcement Of Formal Agreement in practically living economic day by day it has become any requirement which does not be bargained and the purity is based on to the Freedom Principle in Chapter 1338 first (1) KUHP Civil. In effort to give protection against a consumer in Enforcement of Formal Agreement, laws No. 18 in year 1999 about Consumer Protection already managed in such a way procedure Formal Agreement what be enforced in practice with the threat of cancellation if those procedures not able to be fulfilled, namely Formal Agreement in practically can not consist of "Klausula Eksonerasi" or clause that diverts and or to free about responsibility bussinesser. In justice practice, gets amount jurisprudence that has been cancelled with any "Clause Eksonerasi" what does being free of responsibility that person in this business and divert its to the consumer. This thing purposed as form appropriate in law protection to the consumer in court rulling related to the Enforcement of Formal Agreement in community.
\end{abstract}

\section{Kata Kunci: perjanjian baku, perlindungan konsumen}

\section{Pendahuluan}

Sebagai kosekwensi dari asas kebebasan berkontrak yang tersebut dalam Pasal 1338 ayat (1) KUHPerdata ${ }^{2}$, banyak ditemukan berbagai jenis dan bentuk perjanjian dalam masyarakat. Dengan asas kebebasan kebebasan berkontrak (partiy autonomy) tersebut, setiap orang dimungkinkan untuk membuat berbagai jenis perjanjian yang berisi dan berbentuk apa saja. Pembatasan terhadap asas kebebasan berkontrak ini hanyalah undang-undang, ketertiban umum dan kesusilaan baik (vide Pasal 1337 KUHPerdata) ${ }^{3}$. Tentunya adalah tetap terikat kepada syarat syahnya perjanjian sesuai Pasal 1320 KUHPerdata, yaitu: a). Sepakat mereka yang mengikatkan dirinya; b). Kecakapan bertindak di dalam hukum; c). Adanya hal tertentu; dan; d). Suatu sebab yang halal.

Salah satu konsekwensi dari asas kebebasan berkontrak dalam Pasal 1338 ayat (1) KUHPerdata tersebut adalah diberlakukannya perjanjian baku (standard contract) dalam berbagai jenis transaksi konsumen, yaitu transaksi yang terjadi antara konsumen dengan pelaku usaha dalam kaitannya dengan pemenuhan ke-

\footnotetext{
${ }^{1}$ Dosen tetap FH UKI

${ }^{2}$ Pasal 1338 ayat (1) KUHPerdata menyebutkan bahwa semua perjanjian yang dibuat secara sah, berlaku bagi undang-undang bagi mereka yang membuatnya.

${ }^{3}$ Pasal 1337 KUHPerdata menentukan bahwa suatu sebab adalah dilarang apabila bertentangan dengan undang-undang, ketertiban umum dan kesusilaan
}

butuhan hidup manusia. Secara sederhana, perjanjian baku dapat diartikan sebagai suatu jenis perjanjian yang isi dan syarat-syarat perjanjiannya ditetapkan secara sepihak oleh pelaku usaha dan pihak lain atau konsumen tidak dimungkinkan untuk menawar atau menegosiasi isi dan syarat-syaratnya, kecuali dengan pilihan mau atau tidak (take or leave it) ${ }^{4}$.

Berdasarkan penelitian dapat diketahui bahwa dengan alasan praktis dan efisien, ternyata para pelaku usaha dalam menjalankan kegiatan usahanya banyak memberlakukan dan atau menerapkan perjanjian baku. Misalnya saja dalam perjanjian penyimpanan dana, penerapan perjanjian baku oleh pihak bank diperuntukkan untuk melayani jumlah nasabah deposan yang sedemikian banyak, sehingga dengan alasan praktis dan efisien, membuat pihak bank menerapkan perjanjian baku demi pelayanan yang seragam.

Dapat dikatakan bahwa dalam era globalisasi seperti saat ini, pembakuan syarat-syarat perjanjian merupakan model yang tidak dapat dihindarkan. Bagi para pelaku usaha, hal tersebut dimaksudkan sebagai cara untuk mencapai tujuan ekonomi secara efisien,

\footnotetext{
${ }^{4}$ UU No. 8 Tahun 1999 Tentang Perlindungan Konsumen mempergunakan istilah klausula baku yaitu setiap aturan atau ketentuan dan syarat-syarat yang telah dipersiapkan dan ditetapkan terlebih dahulu secara sepihak oleh pelaku usaha yang dituangkan dalam suatu dokumen dan/atau perjanjian yang mengikat dan wajib dipenuhi oleh konsumen.
} 
praktis dan cepat tidak bertele-tele. Tetapi bagi konsumen, justru merupakan pilihan yang tidak menguntungkan karena hanya dihadapkan pada suatu pilihan, yaitu menerima walau dengan berat hati.

Dengan memperhatikan materi atau isi dan syarat-syarat perjanjian baku, banyak ditemukan ketidak seimbangan kedudukan antara konsumen dengan pelaku usaha. Konsumen selalu di pihak yang lemah dibanding dengan pelaku usaha. Hal ini dapat dimaklumi, karena isi dan syarat-syarat yang ada dalam perjanjian baku ditetapkan dan ditentukan secara sepihak oleh pelaku usaha, dan sudah barang tentu, pelaku usaha akan menempatkan dirinya pada posisi yang dominan dibanding dengan konsumen kepada siapa perjanjian baku tersebut hendak diberlakukan. Kedaan ini diciptakan sedemikian rupa melalui pencantuman klausula eksonerasi atau klausula eksemsi, yaitu klausula yang membebaskan tanggung jawab dan/atau kalusula yang mengalihkan tanggung jawab pelaku usaha kepada konsumen, termasuk klausula yang mengurangi atau membatasi pertanggung jawaban pelaku usaha.

Mengingat kedudukan yang tidak seimbang antara pelaku usaha dengan konsumen, pada kondisi mana, pelaku usaha menduduki posisi dominan dalam segala hal, satu dan lainnya mengingat isi dan syarat-syarat perjanjian baku ditetapkan secara sepihak oleh pelaku usaha, maka tidak jarang dalam suatu perjanjian baku, hak dan kepentingan hukum konsumen terabaikan atau bahkan dirugikan.

Dilatar belakangi hal ini, maka perlu adanya piranti hukum yang dapat memberikan perlindungan hukum terhadap konsumen dalam kaitannya dengan pemberlakuan perjanjian baku sehingga konsumen yang mempunyai posisi dominan lemah sedapat mungkin hak dan kepentingan hukumnya tidak dirugikan dan dapat terlindungi. Perlu adanya perlindungan hukum bagi konsumen untuk melindungi hak dan kepentingannya dari perbuatan kesewenangan pelaku usaha dalam kaitannya dengan pemberlakuan perjanjian baku.

\section{Permasalahan}

Bagaimana pemberlakuan perjanjian baku dalam kaitannya dengan perlindungan hukum bagi konsumen?

\section{Tujuan Penulisan}

Tulisan ini bertujuan untuk mengetahui dan menjelaskan pemberlakuan perjanjian baku dalam praktik dan perlindungan hukum yang diberikan kepada konsumen.

\section{Perjanjian Baku Dalam Praktik Kegiatan Ekonomi}

Terminologi perjanjian baku dalam bahasa asing dikenal dengan istilah standaard woorwarden, standaard contract (Belanda), Allgemeine Geshafts Bedingen, Standaard Vertrag, standaard venditionen (Jerman), standardized contract, standard fors of contract (Inggris). Menurut Mariam Darus Badrulzaman, perjanjian standard sebagai perjanjian yang isinya dibakukan dan dituangkan dalam bentuk formulir ${ }^{5}$. Sutan Remi Sjahdeni mengemukakan bahwa perjanjian standar adalah perjanjian yang hampir seluruh klausul-klausulnya dibakukan oleh pemakainya dan pihak yang lain pada dasarnya tidak mempunyai peluang untuk merundingkan atau meminta perubahan. Adapun yang belum dibakukan hanyalah beberapa hal, misalnya yang menyangkut jenis, harga, jumlah, nama, tempat, waktu dan beberapa hal yang spesifik dari objek yang diperjanjikan. Yang dibakukan bukan formulir perjanjian tersebut, melainkan klausul-klausulnya ${ }^{6}$ Di lain pihak, Sidharta mengemukakan bahwa perjanjian standar tidak perlu selalu dituangkan dalam bentuk formulir, walaupun lazim dibuat tertulis. Contohnya, dapat dibuat dalam bentuk pengumuman yang ditempelkan di tempat penjual menjalankan usahanya. Jadi perjanjian standar ialah perjanjian yang ditetapkan secara sepihak, yakni oleh produsen (penyalur produk atau penjual) dan mengandung ketentuan yang berlaku umum (massal), sehingga pihak yang lain (konsumen) hanya memiliki dua pilihan, menyetujui atau menolaknya ${ }^{7}$. Contoh dari perjanjian standar adalah perjanjian penyimpanan dana, polis asuransi, tiket parkir, perjanjian kredit, tiket pesawat dan lainnya.

Beberapa contoh dari pemberlakuan perjanjian baku dalam masyarakat adalah sebagai berikut:

a. Klausula yang terdapat pada faktur pembelian di toko yang menyebutkan "barang yang dibeli tidak dapat dikembalikan lagi.

b. Klausula yang terdapat pada perjanjian penyimpanan dana di lingkungan perbankan yang menentukan klausula pembebasan tanggung jawab dengan menentukan "Sehubungan dengan penatausahaan rekening oleh Bank, Pemilik rekening dengan ini menyatakan membebaskan bank, pejabat atau pegawainya dari segala kerugaian dan/atau pertang-

\footnotetext{
${ }^{5}$ Mariam Darus Badrulzaman, Perlindungan Terhadap Konsumen Dilihat dari sudut Perjanjian Baku (standar), Bandung : Binacipta, 1986, hal.58.

${ }^{6}$ Sutan Remi Sjahdeni, Kebebasan Berkontrak dan Perlindungan Yang Seimbang Bagi Para Pihak Dalam Perjanjian Kredit Bank di Indonesia, Jakarta : Institut Bankir Indonesia,1993, hal.66.

${ }^{7}$ Sidharta, Hukum Perlindungan Konsumen di Indonesia, Jakarta: PT Grassindo, 2000, hal.120.
} 
gung jawaban dan atau gugatan/tuntutan dari pihak manapun juga yang terjadi sebagai akibat dari segala hal, antara lan, pelaksanaan peraturan yang berlaku, terhalangnya komunikasi, pemogokan, keonaran, keadaan darurat serta semua kejadian yang berada di luar kekuasaan bank".

c. Klausula yang terdapat pada tiket pesawat yang menentukan pengangkut tidak bertangung jawab atas kerusakan atau kehilangan atas barang berharga seperti uang, perhiasan, barang elektronik, obat-obatan, dokumen serta surat berharga atau sejenisnya jika dimasukkan ke dalam bagasi.

d. Terkait dengan pemberlakuan perjanjian baku dalam praktik kehidupan ekonomi, ada beberapa pendapat yang berkembang. Diantaranya, Sluiter yang mengatakan bahwa perjanjian baku ini bukan perjanjian, sebab kedudukan pengusaha didalam perjanjian itu adalah seperti pembentuk undang-undang swasta (legio particuliere wetgever). Syarat-syarat yang ditentukan pengusaha di dalam perjanjian itu adalah undang-undang bukan perjanjian. Pitlo yang mengatakannya bahwa perjanjian baku merupakan suatu perjanjian paksa (dwang contract), walaupun secara teoritis yuridis, perjanjian baku ini tidak memenuhi ketentuan hukum undang-undang dan oleh beberapa ahli hukum ditolak namun kenyataannya, kebutuhan banyak masyarakat berjalan dalam arah berlawanan dengan keinginan hukum.

Mariam Darus Badrulzaman berpendapat bahwa perjanjian standar itu bertentangan dengan asas kebebasan berkontrak yang bertanggung jawab, terlebih-lebih dari ditinjau dari asas-asas hukum nasional di mana akhirnya kepentingan masyarakatlah yang didahulukan. Dalam perjanjian standar, kedudukan pelaku usaha dan konsumen tidak seimbang. Posisi yang didominasi oleh pihak pelaku usaha, membuka peluang luas baginya untuk menyalah gunakan kedudukannya. Pelaku usaha hanya mengatur hak-haknya dan tidak dengan kewajibannya. Menurutnya perjanjian ini tidak boleh dibiarkan tumbuh secara liar dan karena itu perlu ditertibkan.

Permasalahan hukum yang sering timbul dari penggunaan perjanjian baku yang bercirikan adanya klausula eksonerasi yang sangat merugikan konsumen banyak dialami konsumen jasa perpakiran yang mengalami kerusakan dan bahkan kehilangan kendaraan di tempat parkir yang tidak diberi ganti kerugian pelaku usaha pengelola parkir. Para pelaku usaha perparkiran berlindung dibalik adanya klausula eksonerasi dalam tiket parkir yang menyatakan bahwa kerusakan atau kehilangan kendaraan di tempat parkir tidak merupakan tanggung jawab pengelola parkir. Demikian juga dialami konsumen loundry yang sering dirugikan pelaku usaha akibat pencantuman klausula eksonerasi dalam bentuk pembatasan tanggung jawab.

Pernah terjadi suatu kasus yang dialami Ny. Nurhayati (bukan nama sebenarnya) yang mencucikan sebuah Bed Cover warna putih berbunga-bunga merah dan biru untuk ukuran tempat tidur nomor satu di laundry dan dry cleaning service di Rawamangun. Pada nota tertulis akan selesai pada tanggal tertentu, namun pada tanggal tersebut, Nurhayati menanyakan hasil cucian, namun petugas tetap menjawab cucian belum selesai. Seminggu kemudian petugas tetap menjawab cucian belum selesai. Setelah beberapa kali ditanya, pihak laundry akhirnya menyatakan, bahwa bed cover milik Ny. Nurhayati hilang.

Ketika Ny. Nurhayati meminta pertanggungjawaban laundry, dengan enteng petugas berkata, sesuai peraturan yang tertulis dalam nota, apabila barang cucian hilang atau rusak, pihal laundry memberi ganti rugi sebesar lima kali ongkos laundry. Jadi, dengan kehilangan tersebut $\mathrm{Ny}$. Nurhayati hanya mendapat ganti rugi sebesar Rp. 6.000.00 X 5 - Rp. 30.000.00. Padahal, sebagai hadiah dari suami, bed cover itu sangat berharga. Bukan karena harganya, tetapi barang tersebut mempunyai nilai khusus.

Akibat dari penggunaan perjanjian baku yang banyak menimbulkan kerugian bagi konsumen, dalam praktik peradilan ditemukan sejumlah jurisprudensi yang memihak kepada konsumen yang membatalkan perjanjian baku yang memuat kalusula eksonerasi, diantaranya adalah ebagai berikut:

a. Putusan MARI No. 124 PK/Pdt/2007 yang membatalkan klausula eksonerasi yang ada pada tiket parkir yang menyatakan pengelola parkir tidak bertanggung jawab atas kehilangan, kerusakan, kecelakaan aas kenderaan ataupun kehilangan barang yang terdapat di dalam kendaraan atau yang menimpa orang yang menggunakan area parkir pihak pengelola.

b. Putusan Pengadilan Negeri Jakarta Pusat No. 309/Pdt.G/2007/PN.Jkt.Pst yang memutuskan bahwa klausula baku yang terdapat pada tiket angkutan udara yang menentukan bahwa pengalihan tanggung jawab atas kerugian yang ditimbulkan karena pembatalan dan/atau keterlambatan pengangkutan adalah batal demi hukum dan tidak mempunyai kekuatan hukum mengikat.

Bila dirunut ke belakang, sesungguhnya penggu- 
naan kalusla eksonerasi sebagaimana diuraikan diatas oleh jurisprudensi MARI telah diakui sebagai suatu penyalahgunaan keadaan dan kedudukan ekonomi (misbruik van omstandingheden) sebagai suatu alasan baru dalam membatalkan perjanjian sebagaimana tersebut dalam putusan MARI No. 3431 K/Pdt/1985 tanggal 4 Maret 1987 dan No. 1904 K/Sip/1982 tanggal 28 Januari 1984.

\section{Perlindungan terhadap Konsumen dalam Pemberlakuan Perjanjian Baku}

Perkataan konsumen bukanlah hal yang baru dikalangan masyarakat. Dalam pengertian yang sederhana, konsumen berarti adalah pemakai yang berasal dari kata consumer. Secara harfiah arti kata consumer itu adalah (lawan dari produsen) setiap orang yang menggunakan barang ${ }^{8}$. Dalam kamus Inggris-Indonesia, consumer adalah pemakai atau konsumen ? Selanjutnya menurut Kamus Besar Bahasa Indonesia, kosumen adalah pemakai barang hasil produksi atau pemakai jasa (pelanggan $)^{10}$. UU No. 8 tahun 1999 tentang Perlindungan Konsumen memberikan rumusan konsumen yaitu setiap orang pemakai barang dan atau jasa yang tersedia dalam masyarakat, baik bagi kepentingan diri sendiri, keluarga, orang lain maupun mahkluk hidup lain dan tidak untuk diperdagangkan.

Dalam kaitannya dengan perlindungan terhadap konsumen, menurut Kamus Besar Bahasa Indonesia, "perlindungan" sebagai kata benda diartikan sebagai 1). Tempat berlindung; dan 2). hal (perbuatan), dan sebagainya memperlindungi. Kata "memperlindungi" (kata kerja) mempunyai arti menjadikan atau menyebabkan berlindung. ${ }^{11}$ Sudikno Mertokusu- mo mengemukakan, "perlindungan hukum adalah adanya jaminan hak dan kewajiban untuk manusia dalam rangka memenuhi kepentingan sendiri maupun didalam hubungan dengan manusia lainnya. Kepentingan manusia yang dilindungi oleh hukum biasa disebut hak dan memberikan wewenang kepada seseorang untuk melakukan perbuatan dapat dipersamakan kepada siapun dan sebaliknya setiap orang harus menghormati hak itu". ${ }^{12}$

\footnotetext{
${ }^{8}$ AS. Hornby, Oxford Advance Learners Dictionary of Current English, Oxford University Press, Oxford 1987, hal. 183.

${ }^{9}$ John. M. Echols \& Hasan Sadely, Kamus Inggris-Indonesia, Jakarta : Gramedia, 1986, hal. 124.

${ }^{10}$ Departemen Pendidikan Nasional, Kamus Besar Bahasa Indonesia, Jakarta : Balai Pustaka, 2005, hal. 590.

${ }^{11}$ Departemen Pendidikan Nasional, op. cit, halaman 674.

${ }^{12}$ Sudikno Mertokusumo, Mengenal Hukum, Yogyakarta : Liberty, 2002, halaman 25.
}

Perlindungan hukum merupakan upaya yang diatur dalam undang-undang untuk mencegah terjadinya pelanggaran hukum. Untuk itu, agar tidak terjadi pelanggaran hukum yang dapat merugikan kepentingan umum dapat dilakukan dengan menegakkan aturan-aturan hukum guna menjamin perlindungan hukum tetap berlangsung selama jangka waktu tertentu. Oleh sebab itu, dalam perlindungan hukum terkait juga masalah penegakan hukum artinya, keberhasilan penegakan hukum akan memberikan perlindungan hukum bagi masyarakat secara optimal.

Saat ini, perlindungan terhadap konsumen telah diatur secara khusus dalam UU No. 8 tahun 1999 tentang Perlindungan Konsumen, Lembaran Negara tahun 1999 No. 3821. Undang-undang ini merupakan salah satu piranti hukum yang berfungsi sebagai pedoman dan landasan bagi perekonomian Indonesia dalam menghadapi era globalisasi, khususnya dalam kaitannya dengan kepentingan perlindungan terhadap konsumen.

Penjelasan Umum UU No. 8 tahun 1999 mengemukakan bahwa dalam kondisi dan fenomena kedudukan pelaku usaha dan konsumen yang tidak seimbang, konsumen menjadi objek aktivitas bisnis untuk meraup keuntungan yang sebesar-besarnya oleh pelaku usaha melalui kiat promosi, cara penjualan serta penerapan perjanjian standar yang merugikan konsumen.

Tujuan utama dari undang-undang ini adalah untuk memberdayakan konsumen dengan meningkatkan harkat dan martabat konsumen. Perlindungan konsumen sebagaimana dimaksud dalam undang-undang ini adalah segala upaya yang menjamin adanya kepastian hukum dan memberi perlindungan kepada konsumen melalui asas keseimbangan. Bukan berarti undang-undang ini tidak melindungi hak dan kepentingan produsen atau pelaku usaha. Perlindungan diberikan kepada masing-masing pihak melalui pengaturan hak dan kewajiban masing-masing pihak.

Dalam kaitannya dengan perjanjian baku, Undang Undang Perlindungan Konsumen ini telah mengatur secara limitatif tentang batasan-batasan yang harus dipenuhi pelaku usaha manaka pelaku usaha dalam menawarkan barang dan/atau jasa yang diproduksinya melalui perjanjian baku. Pembatasan ini dimaksudkan untuk memberikan perlindungan bagi konsumen atas resiko pemberlakuan perjanjuian baku oleh pelaku usaha. Hal ini diatur dalam Pasal 18 yang menentukan sebagai berikut:

1. Pelaku usaha dalam menawarkan barang dan/ atau jasa yang ditujukan untuk diperdagangkan dilarang memuat atau mencantumkan klausula 
baku pada setiap dokumen dan/atau perjanjian, apabila:

a. Menyatakan pengalihan tanggung jawab pelaku usaha.

b. Menyatakan bahwa pelaku usaha berhak menolak penyerahan kembali barang yang dibeli konsumen.

c. Menyatakan bahwa pelaku usaha berhak menolak penyerahan kembali uang yang dibayarkan atas barang dan/atau jasa yang dibeli oleh konsumen.

d. Menyatakan pemberian kuasa dari komsumen kepada pelaku usaha, baik secara langsung maupun tidak langsung untuk melakukan segala tindakan sepihak yang berkaitan dengan barang yang dibeli oleh konsumen secara angsuran.

e. Mengatur perihal pembuktian atas hilangnya kegunaan barang atau pemanfaatan jasa yang dibeli oleh konsumen.

f. Memberi hak kepada pelaku usaha untuk mengurangi manfaat jasa atau mengurangi harta kekayaan konsumen yang menjadi objek jual beli jasa.

g. Menyatakan tunduknya konsumen kepada peraturan yang berupa aturan baru, tambahan, lanjutan dan/atau perubahan lanjutan yang dibuat sepihak oleh pelaku usaha selama masa konsumen memanfaatkan jasa yang dibelinya.

h. Menyatakan bahwa konsumen memberi kuasa kepada pelaku usaha untuk pembebanan hak tanggungan baik gadai atau hak jaminan terhadap barang yang dibeli oleh konsumen secara angsuran.

2. Pelaku usaha dilarang mencantumkan klausula baku yang letak atau bentuknya sulit terlihat atau tidak dapat dibaca secara jelas atau yang pengungkapannya sulit dimengerti.

3. Setiap klausula baku yang telah ditetapkan oleh pelaku usaha pada dokumen atau perjanjian yang memenuhi ketentuan sebagaimana dimaksuddalam ayat (1) dan ayat (2) dinyatakan batal demihukum.

4. Pelaku usaha wajib menyesuaikan klausula baku yang bertentangan dengan undang-undang ini.

Dalam berbagai dokumen pemberlakuan perjanjian baku dalam praktik, diantaranya yang diterapkan dalam tiket parkir, polis asuransi, perjanjian penyim-

panan dana di lingkungan perbankan, melalui Pasal 18 dapat diberikan analisis atas pemberlakuan perjanjian baku sebagai berikut:

\section{Bentuk Dan Letak}

Bagian ini terdapat dalam Pasal 18 ayat (2) UUPK yang menentukan bahwa pelaku usaha dilarang mencantumkan klausula baku yang letak atau bentuknya sulit terlihat atau tidak dapat dibaca secara jelas atau yang pengungapannya sulit dimengerti.

Dalam UUPK maupun penjelasannya, tidak disebutkan leih lanjut klausula baku seperti apakah yang dapat dinyatakan sebagai klausula yang sulit terlihat, tidak dapat dibaca secara jelas serta pengungkapannya sulit dimengerti, padahal demi kepastian hukum per- lu adanya suatu kriteria atau acuan mengenai klausula baku seperti apa yang dapat dinyatakan sebagai klausula baku yang bentuknya sulit terlihat, tidak dapat dibaca secara jelas serta pengungkapannya sulit dimengerti. Mengingat tidak ada penjelasan tersebut, maka upaya yang dilakukan adalah dengan mengadakan penafsiran terhadap undang-undang yang bersangkutan.

Dalam usaha mencari dan menentukan kehendak pembentuk undang-undang terhadap ketentuan dalam Pasal 18 ayat (2) UUPK, maka harus dipergunakan penafsiran gramatikal (taatkundige interpretatie), yaitu penafsiran yang dilakukan terhadap peristilahan/kata-kata atau tata kalimat dalam suatu konteks bahasa yang digunakan pembuat undang-undang dalam merumuskan peraturan perundang-undnangan tertentu ${ }^{13}$.

Dalam menafsirkan isi Pasal 18 ayat (2) UUPK sebagaimana diuraikan diatas, maka dilakukan penafsiran terhadap kata-kata: a). Letak; b). Bentuk; c). Dibaca; dan; d). Pengungkapan;

Dan ternyata kata letak adalah berarti, tempat beradanya sesuatu atau kedudukan, keadaan. Dalam konteks kata letak yang terdapat dalam Pasal 18 ayat (2) UUPK, maka maksud kata letak adalah tempat beradanya sesuatu, yang dalam hal ini adalah tempat beradanya klausula baku.

Kata "bentuk" mempunyai arti "lengkung, lentur, bangun, gambaran, rupa/wujud, system/susunan, wujud yang diampilkan (tampak), acuan atau susunan kalimat, kata bantu bilangan bagi benda yang berbentuk (cincin, gelang, dan sebagainya). Dalam konteks kata "bentuk" yang terdapat dalam Pasal 18 ayat (2) UUPK, maksud kata "bentuk" adalah rupa atau wujud, yang dalam hal ini adalah rupa atau wujud suatu klausula baku yang terdapat dalam perjanjian baku.

Dalam konteks kata "dibaca" yang terdapat dalam Pasal 18 ayat (2) UUPK tersebut diatas, mak-

\footnotetext{
${ }^{13}$ Dalam melakukan penafsiran menggunakan Kamus Besar Bahasa Indonesia, Departemen Pendidikan Nasional, Penerbit Balai Pustaka, tahun 2005.
} 
sudnya adalah melihat serta memahami isi dari apa yang tertulis, yang dalam hal ini adalah melihat serta memahami isi dari suatu klausula baku yang terdapat dalam perjanjian baku.

Sedangkan kata ungkap yang merupakan kata dasar dari "pengungkapan" adalah berarti melahirkan perasaan hati, menunjukan, membuktikan, menyingkapkan, mengemukakan, menyatakan, memaparkan, menerangkan dengan jelas, menguraikan. Dalam konteks kata "pengungkapan" yang tersebut dalam Pasal 18 ayat (2) UPK, maksud dari kata "pengungkapan" adalah memaparkan dan menerangkan dengan jelas maksud dari suatu klausula baku yang dalam hal ini adalah klausula baku yang terdapat dalam perjanjian baku haruslah secara jelas memaparkan dan menerangkan maksud dan susbtansi dari klausula baku dimaksud.

Berdasarkan uraian diatas dapat disimpulkan bahwa maksud dari Pasal 18 ayat (2) UUPK adalah larangan bagi pelaku usaha untuk mencantumkan klausula baku dalam suatu perjanjian yang:

- Keberadaan klausula baku tersebut dalam dokumen perjanjian sulit terlihat.

- Rupa atau wujud klausula tersebut dalam dokumen perjanjian sulit terlihat.

- Sulit untuk melihat serta memahami denganjelas klausula tersebut.

- Klausula tersebut tidak memaparkan dan menerangkan isi serta maksudnya.

\section{Kesimpulan}

Pemberlakuan perjanjian baku dalam praktik kehidupan ekonomi sehari-hari sudah merupakan suatu ranya para pelaku usaha benar-benar memperhatikan syarat-syarat dan ketentuan tentang pemberlakuan perjanjian baku dalam masyarakat sebagaimana diatur dalam undnag-undang, khususnya Pasal 18 UU No. 8 Tahun 1999 Tentang Perlindungan KonsumenPemerintah sebagai eksekutif kiranya dapat melakukan pengawasan dan pembinaan terhadap para pelaku usaha yang memberlakukan perjanjian baku dalam mendistribusikan produk barang dan/atau jasa yang dihasilkan sehingga hak dan kepentingan konsumen tidak dirugikan.

\section{Daftar Pustaka}

\section{Buku}

Mariam Darus Badrulzaman, Perlindungan Terhadap Konsumen Dilihat dari sudut Perjanjian Baku (standar), Bandung: Binacipta, 1986.

Sudikno Mertokusumo, Mengenal Hukum, Yogyakarta: Liberty, 2002.

AZ Nasution, Konsumen dan Hukum, Tinjauan Sosial, Ekonomi dan Hukum Pada Perlindungan Konsumen Indonesia, Jakarta: Pustaka Sinar Harapan, 1995.

Hulman Panjaitan, Kumpulan Kaidah Hukum Putusan Mahkamah Agung Republik Indonesia Tahun 1953 - 2008 Berdasarkan Penggolongannya, Jakarta: Kencana, 2015.

Sutan Remi Sjahdeni, Kebebasan Berkontrak dan Perlindungan Yang Seimbang Bagi Para Pihak Dalam Perjanjian Kredit Bank di Indonesia, Jakarta: Institut Bankir Indonesia,1993.

Sidharta, Hukum Perlindungan Konsumen di Indonesia, Jakarta: PT Grassindo, 2000.

Hukum Perlindungan Konsumen Indo- 
keharusan yang tidak dapat ditawar-tawar dan keab- sahannya didasarkan kepada asas kebebasan berkont- rak yang ada dalam Pasal 1338 ayat (1) KUHPerdata. Dalam upaya memberikan perlindungan terhadap konsumen dalam pemberlakuan perjanjian baku, UU No. 18 tahun 1999 tentang Perlindungan Konsumen telah mengatur sedemikian rupa syarat-syarat per- janjian baku yang dapat diberlakukan dalam praktik dengan ancaman kebatalan bila syarat-syarat tersebut tidak dipenuhi, diantaranya perjanjian baku dalam praktiknya tidak boleh memuat kalusula eksonerasi atau klausula yang mengalihkan dan/atau mebebas- kan tanggung jawab pekaku usaha.

\section{Saran}

Dalam kaitannya dengan upaya perlindungan hu- kum terhadap konsumen sesuai undang-undang, ki- nesia, Jakarta: Grassindo, 2000.

\section{Perundang-undangan}

Subekti R \& R. Tjitrosudibio, Kitab Undang Undang Hukum Perdata, Jakarta: Pradnya Paramita, 1987

\section{Kamus}

Kamus Besar Bahasa Indonesia, Jakarta: Balai Pus- taka, 2005.

John M. Echols dan Hasan Sadely, Kamus Inggris- Indonesia, Jakarta: Gramedia, 1986.

Hornby AS, Oxford Advance Learners Dictionary of Current English, Oxford: University Press Ox- ford, 1987. 